Revista Iberoamericana, Vol. LXXVIII, Núm. 240, Julio-Septiembre 2012, 585-604

\title{
UN EPISTOLARIO APÓCRIFO PARA EL ARTISTA ADOLESCENTE: VARGAS LLOSA Y EL ENSAYO HECHO CARTA
}

\author{
POR \\ Vicente Cervera Salinas \\ Universidad de Murcia
}

Ultimadas en Lima, el 10 de mayo de 1997, las Cartas a un joven novelista de Mario Vargas Llosa ${ }^{1}$ plantean una renovación del procedimiento literario de la epístola apócrifa como modo de exposición reflexiva en torno al fenómeno de la escritura dentro de la historia del género "ensayo". ${ }^{2}$ El término “apócrifo" ha de entenderse aquí en un sentido restrictivo, puesto que sólo alude al carácter imaginario de la relación epistolar y no a la identificación del redactor interno de las cartas con el autor real de la obra, donde sí se establece la identidad absoluta, tratándose en todo momento de una exposición de ideas y argumentos propios del escritor peruano y aplicables siempre a su persona. Las doce cartas que dan título al conjunto pautan sus criterios en torno a la prosa de ficción y establecen el inventario particular de los títulos que constituyen la biografía lectora de su autor. En este "ensayo” hilvana Vargas Llosa una poética de la novela sin ceder en su función de gran fabulador, ya que se conforman como epístolas apócrifas destinadas a un aprendiz de novelista que solicita información privilegiada y que se encuentra con el testimonio de la experiencia de un autor consagrado en su vertiente de lector y conocedor del “corpus” histórico de la novela. La obra, por lo tanto, combina distintos registros genéricos: el ensayo, la epístola fictiva y la teoría sobre la

1 Las primeras ediciones de la obra aparecieron en Buenos Aires (Ed. Ariel) y en Barcelona (Eds. ArielPlaneta), ambas en 1997. Círculo de Lectores la editó por vez primera en 2001. Manejo la edición de Obras completas. Ensayos literarios I de Galaxia Gutenberg-Círculo de Lectores de 2006. Figura como la última de las obras de este volumen, en las páginas 1291-1389. Citaré siempre esta edición. Entre la redacción del presente artículo y su publicación tuvo lugar la concesión en 2010 del Premio Nobel de literatura a Mario Vargas Llosa. Los responsables de la revista y el autor del trabajo quieren expresar por este medio su felicitación al novelista peruano.

2 Una visión de conjunto del género ensayístico, donde se recogen las últimas aportaciones de destacados especialistas teóricos en la materia: Aullón de Haro, "El género ensayo, los géneros ensayísticos y el sistema de géneros" (Cervera, El ensayo 13-24); Arenas Cruz, "El ensayo como clase de textos de género argumentativo" (Cervera, El ensayo 43-58); Pozuelo Yvancos, "El género literario Ensayo" (Cervera, El ensayo 179-191) puede encontrarse en el volumen editado por Vicente Cervera, Belén Hernández y María Dolores Adsuar. 
novela, cuya articulación es forjada por la mano maestra del novelista peruano, que de este modo aborda los diversos intereses de la creatividad literaria que desde el comienzo de su dedicación a la escritura tuvo presentes y que, merced a este título sintético y conclusivo, consigue aunar, convirtiendo así las Cartas a un joven novelista en una suerte de sumario de su biografía literaria. ${ }^{3}$

En efecto, la evolución de la escritura de ensayos sobre materia literaria es una de las constantes en la bibliografía de Vargas Llosa. Un modo de concebir este género caracteriza al escritor peruano, basado en la integración del proceso discursivo intelectual con la dimensión estilística y la atención a las herramientas lingüísticas de gran calado expresivo. Sus ensayos se alzan como obras de resonancia creativa que no sólo nos permiten adentrarnos en los vericuetos teóricos del autor, sino que también subrayan esa cualidad formal que vindicó G. Lukács “como función preeminente del ensayista” (15-16). José Miguel Oviedo agrupa la obra de Mario Vargas Llosa junto a Octavio Paz, Carlos Fuentes, Guillermo Cabrera Infante y Augusto Monterroso en su capítulo “Creación y crítica” de su Breve historia del ensayo hispanoamericano (139-41); y John Skirius subraya asimismo, como función axial en los ensayos de Vargas Llosa, su prosa "cristalina y elegante como una estatua griega clásica”, encomiando su "estilo pulido y la vitalidad de sus argumentos” al acercarse a su figura en su monumental El ensayo hispanoamericano del siglo $X X$ (641). Son muchos y muy variados los intereses culturales que han ocupado la atención del escritor en el seno de su “corpus” ensayístico. Desde la novela de caballerías hasta las más recientes publicaciones de las últimas generaciones de narradores hispanoamericanos y españoles, el arco literario que tensa la mano de Vargas Llosa abarca una multitud de épocas, naciones, estilos y problemáticas inherentes a la composición prosística, aunque cabría observar, en un recorrido más atento y pausado, cuáles son verdaderamente las referencias más abundantes y dónde se revela la verdadera “pasión” por esa “postulación de la realidad” que descubre el peruano como denominador común en su experiencia como lector de prosa ficcional.

En este sentido cabría aislar en dos áreas específicas sus aportaciones especulativas más destacadas. Por un lado, su interés por la realidad cultural hispanoamericana, que liga la preocupación del novelista con la del “zoon politikón” que ha desarrollado Vargas Llosa y que le llevó a postularse como presidente de la República del Perú en las elecciones de 1990. ${ }^{4}$ Agruparíamos aquí títulos emblemáticos como García Márquez:

\footnotetext{
3 “Mario Vargas Llosa se sirve de la forma epistolar para elaborar un resumen de su concepto de la novela y de sus personales métodos de análisis. De hecho, el mecanismo formal es un recurso al que el autor no concede la menor importancia. Nada o casi nada sabemos ni se nos dice de este "joven novelista”, pretexto y recurso” que enmascara la verdadera naturaleza de la obra” (Marco 25).

4 En sus memorias recapitula así el autor el resultado de las urnas: "El programa para el que yo pedí un mandato y que el pueblo peruano rechazó, se proponía sanear las finanzas públicas, acabar con la inflación y abrir la economía peruana al mundo, como parte de un proyecto integral de desmantelamiento

Revista Iberoamericana, Vol. LXXVIII, Núm. 240, Julio-Septiembre 2012, 585-604
ISSN 0034-9631 (Impreso)
} 
historia de un deicidio (1971), ${ }^{5}$ La utopía arcaica. José María Arguedas y las ficciones del indigenismo (1996) o El viaje a la ficción (2008), donde plantea una revisión de la crítica literaria sobre la obra de Juan Carlos Onetti, como homenaje en el centenario de su nacimiento (1909-2009). Paralelamente, ha desarrollado el autor peruano una línea de acción ensayística centrada en la comprensión de la novela, en especial desde la época del gran auge del género en las literaturas europea y norteamericana, es decir, a partir del siglo xix hasta la actualidad, sin descuidar en ningún momento la producción contemporánea y las creaciones más recientes, ámbito al que siempre ha dedicado un enorme interés crítico.

Abriríamos esta sección con la que me atrevo a considerar su obra más personal en el género del ensayo literario, La orgía perpetua. Flaubert y Madame Bovary (1975), obra de una enorme enjundia crítica, donde revela Vargas Llosa su fascinación por el texto flaubertiano y su protagonista femenina, atraídos desde una multitud de perspectivas complementarias: la autobiografía lectora, el estudio exhaustivo de las formas narrativas que componen el universo textual, los estratos semánticos y culturales implicados y, sobre todo, la admiración por la capacidad de crear vida en la novela e insertarla en un universo autónomo y complejo, que perpetra con suma perfección la imaginación plasmada en palabras del demiurgo, del "deicida”, como gusta definir el peruano al escritor colmado y cabal. ${ }^{6}$ Vargas Llosa descubre, elogia y aun "envidia” en Flaubert la transformación del acto de escritura en una realidad íntima, densa, auténtica, insustituible y, sobre todo, "orgiástica": la "luxure de la plume” de la que hablaba el novelista francés y que con tanta precisión y sutileza recrea el peruano en su ensayo, subrayando que Flaubert "llegó a la conclusión de que una intensa actividad erótica era perjudicial a la creación literaria y de que, por el contrario, una cierta contención beneficiaba al novelista” (Orgía 90).7 Como bien señala Joaquín Marco en la edición

de la estructura discriminatoria de la sociedad, removiendo su sistema de privilegio, de manera que los millones de pobres y marginados pudieran por fin acceder a aquello que Hayek llama la trinidad inseparable de la civilización: la legalidad, la libertad y la propiedad [...]” (Pez 533).

5 "Hay varios antecedentes críticos del autor que pautan la trayectoria que lleva a su Historia de un deicidio: su prólogo a José María Arguedas, su ensayo sobre Sebastián Salazar Bondy y la vocación del escritor en el Perú, su discurso de Caracas con el homenaje a Oquendo de Amat, sus estudios sobre Tirant lo Blanc, etc. Todos estos textos claves caracterizaban ya a Vargas Llosa como ese peculiar tipo de crítico que T. S. Eliot señaló como ‘El crítico que es además poeta’ (o novelista, o autor teatral); es decir, aquel cuyo trabajo crítico es un subproducto de su actividad como creador, sin la cual aquel esfuerzo no se explica” (Oviedo, Mario 318).

6 Vargas Llosa desarrolla in extenso esta noción en su exhaustivo y complejo estudio sobre la novela de García Márquez, donde no escatima imágenes de progenie simbólica, psicológica y demonológica para referirse a la figura del novelista como suplantador de Dios y ladrón de la realidad objetiva (Vargas Llosa, García Márquez 183 y ss.).

7 “Esa entrega, descrita por Vargas Llosa ‘tan vehemente y total como la del coito', no equivaldría, como erróneamente pudiera interpretarse, a un abandono muelle al hedonismo extático y pasivo, sino un

\footnotetext{
Revista Iberoamericana, Vol. LXXVIII, Núm. 240, Julio-Septiembre 2012, 585-604 ISSN 0034-9631 (Impreso) ISSN 2154-4794 (Electrónico)
} 
española de la Obra Completa del peruano, este ensayo permite un adentramiento hondo y sustantivo no sólo en la producción crítica, sino también en su propia obra novelística, funcionando como pasaje teórico entre dos costas: la obra analizada y la obra inventada o ficcional, "porque el estudio de Vargas Llosa nace de sus propias preocupaciones creadoras" (19). ${ }^{8}$

En este mismo bloque de títulos ensayísticos centrados en la historia de la novela a partir del siglo XIX vendrían a sumarse posteriores entregas críticas, entre las que cabría destacar títulos como La verdad de las mentiras (1990) o La tentación de lo imposible (2004). Este último será diseñado de manera paralela a su anterior aproximación a la novela francesa, ya que indaga en la particular magnitud épica de Los miserables de Victor Hugo, tratando de desbrozar los distintos estratos narrativos, históricos, espirituales y políticos que tejen el fresco de esta "desmesurada narración”, ejemplo sublime de novela-total y emblema asimismo su autor de cumplido deicida, capaz de reinventar un mundo a partir de unas acciones concretas que registra la historia. ${ }^{9}$ Diversamente, en el primer título ahora aludido, se propone un recorrido prismático y poliédrico acerca de los diversos títulos que han ejercido influjos y establecido presencias vivas en la conformación de la personalidad literaria de Vargas Llosa. Una visión amplia y universal del archivo novelístico es el que ejercita el peruano como modo peculiar de afianzar su concepto de la creación como establecimiento genuino de un nuevo orden o sistema que se añade al mundo, participando de su realidad, pero también postulando unas coordenadas propias e inventadas que expresan esa nueva "verdad" inderogable

auténtico derroche feraz de energías físicas y, ¿por qué no decirlo?, sobre todo espirituales, tendentes a la consumación plena del gozo, de la frase cabal y voluptuosamente perfecta, de la palabra oportuna y atrayente, de la perspectiva adecuada y penetrante. El consejo que, extraído con no menos tenaz detenimiento por Vargas Llosa de la maraña epistolar flaubertiana, repetía a su amigo Ernest Feydeau, según el cual debía 'reservar su priapismo para el estilo', encaja y casa perfectamente con la creciente obstinación estilística de Flaubert” (Cervera, “Elogio” 121).

8 "Sus análisis, pese a utilizar una selecta bibliografía y proponer un amplio repertorio metodológico e histórico literario, brotan de sus íntimos problemas como creador, bien distintos por formación, origen y resultados de la narrativa francesa que triunfó por poco tiempo en el catálogo de su editor Carlos Barral” - dice el prologuista, aludiendo a la difusión editorial de la novela francesa de los años cincuenta y siguientes en España, merced a la labor de Seix-Barral: el llamado nouveau roman, la novela “behaviorista”, etc. (19). También Oviedo coincide en la apreciación, al señalar "la deuda sentimental e intelectual de Vargas Llosa con su maestro [Flaubert]” (Oviedo, Mario 331).

9 "Lo que en su origen era una historia más o menos compacta -la del ex presidiario Jean Valjean que, ganado para el bien por la bondad del obispo Myriel, se redime y eleva en la escala moral a alturas insospechadas, después de un martirologio civil-, se convierte, doce años después, en una selva: a la historia central se injertan otras, independientes o parásitas, y múltiples digresiones filosóficas, sociales y religiosas. Este crecimiento es a ratos desproporcionado, anárquico [...]. Y, sin embargo, precisamente debido a su naturaleza torrencial, émula del vértigo de la vida, Las miserables, [...] nos sigue pareciendo a los lectores, desde que el libro se publicó, una de las más memorables historias que haya producido la literatura” (Tentación 29).

Revista Iberoamericana, Vol. LXXVIII, Núm. 240, Julio-Septiembre 2012, 585-604
ISSN 0034-9631 (Impreso) 
y plena que surge de las "mentiras" o fantasías ideadas por la especulación creadora de un artista de palabras: el novelista. Las grandes referencias de la novela europea (los existencialistas, como Albert Camus, Jean-Paul Sartre o Graham Greene) conviven en este museo personal de la narración con los artífices de la gran novela erótica del Xx (Scott Fitzgerald, Vladimir Nabokov, Junichiro Tanizaki, Henry Miller), de la novela de contexto político (El tambor de hojalata, El gatopardo, Un día en la vida de Iván Denisovich, Doctor Zhivago) o de la novela psicológica o propiamente "intelectual" (Virginia Woolf, James Joyce, Thomas Mann, Herman Hesse, Elías Canetti). El resultado es proteico y, al mismo tiempo, coherente, pues vertebra la biografía novelística del autor, sin descuidar su comprensión reflexiva sobre la creación literaria, ya que-según testimonia en el artículo preliminar-

[...] en el corazón de todas ellas llamea una protesta. Quien las fabuló lo hizo porque no pudo vivirlas y quien las lee (y las cree en la lectura) encuentra en sus fantasmas las caras y aventuras que necesitaba para aumentar su vida. Esa es la verdad que expresan las mentiras de las ficciones: las mentiras que somos, las que nos consuelan y desagravian de nuestras nostalgias y frustraciones. (Vargas Llosa, Verdad 12)

Como vemos, una particular teoría o filosofía de la creación que articula Vargas Llosa a partir de su experiencia lectora y, complementariamente, de su actividad como novelista.

Desde estas premisas, las Cartas a un joven novelista vendrían a configurar una suerte de síntesis o "summa" teórica de la trayectoria literaria de su autor (en la doble articulación de la misma arriba establecida). Pero, en esta ocasión, el recurso utilizado por el escritor se basa en la utilización de la herramienta epistolar como ficción que provoque la concatenación de ideas y argumentos de tipo ensayístico sobre la novela y su venturosa existencia. El contexto en que se inscribe la obra partiría del modelo de la carta como canal de presentación ideológico, cultivado en la filosofía y la literatura a partir del "siglo de las luces", entendiendo el fenómeno como renovación del uso de la carta. Si antiguamente fue vehículo de tradición doctrinal en la literatura clásica (Cicerón, Horacio, Séneca), a partir del siglo xviII adquirirá un sesgo divulgador y un carácter informativo y polémico. Será el modelo utilizado por Voltaire en sus cartas de presentación sobre la filosofía de Newton a los franceses, o el que apuntala las Cartas persas (1721) de Montesquieu. El estilo epistolar utilizado en esta dirección permitía aunar el desglose teórico con el filo de la sátira de costumbres o combinar la polémica con la dimensión más doméstica o familiar del discurso, cuyo "marco" fictivo (la redacción y lectura de la carta) forja un estilo y un contexto que arraiga fuertemente en la propia médula del ensayo como género "polimorfo", según la acertada definición de Sánchez Blanco: "El carácter informativo y polémico es mucho más decisivo en la carta moderna que en la epístola, por ejemplo, senequiana” (29). En España se extenderá el

\footnotetext{
Revista Iberoamericana, Vol. LXXVIII, Núm. 240, Julio-Septiembre 2012, 585-604 ISSN 0034-9631 (Impreso)

ISSN 2154-4794 (Electrónico)
} 
auge de su composición mediante su magistral cultivo de la mano de Benito Jerónimo Feijoo, con sus Cartas eruditas y curiosas (1742-1760) o José Cadalso con las Cartas marruecas (1793). ${ }^{10}$ Su imbricación con la novela o su derivación como texto histórico paralelo, importante para el conocimiento de la biografía o la poética de los escritores, ha sido fecunda y diversa en la literatura contemporánea a partir del romanticismo, pero sólo en determinados casos alcanza el estatuto de formulación ensayística. Un recuento minucioso de la escritura epistolar en los autores ingleses a partir de William Blake, como el realizado por Paloma Tejada, nos permite evaluar la trascendencia de su cultivo, pero también descubrimos cómo son escasos los títulos que impriman una dimensión ficcional de la carta ("Género" 188-190). Nombres como los de Robert Louis Stevenson o Virginia Woolf merecerían figurar en la nómina de las brillantes excepciones en el uso de la carta "apócrifa", escrita como peculiar modalidad para el desarrollo ensayístico de una serie de opiniones o argumentos sobre temas variopintos. La escritora británica incluyó su carta en la colección The Death of the Moth and Other Essays, en 1932, y se sirvió del procedimiento para aquilatar su concepto sobre la poesía como expresión genuina de la auto-conciencia creadora, para lo cual el mecanismo imaginario del "joven escritor" era pertinente e idóneo, debido a la necesidad de objetivar y "pasar en claro" las intuiciones propias de modo que sirvieran como guía, consejo o método (camino) para el neófito. ${ }^{11}$ Con casi medio siglo de anticipación, Robert Louis Stevenson comprendería asimismo la eficacia del procedimiento de la invención epistolar en un escrito tan lleno de viveza, inteligencia y perspicacia como lo es su ensayo Letter to a Young Gentleman Who Proposes to Embrace the Career of Art."

Sobresale en la epístola stevensoniana, en tanto anticipo de alguno de los elementos constitutivos de la colección de cartas de Vargas Llosa, el tono de "consejo" en clave pedagógica pero, al mismo tiempo, liberada de todo peso doctrinal y riguroso, más tendente a plantear las cuestiones vitales y éticas que canalizan la existencia de un escritor profesional. En especial, es memorable la distinción propuesta por el novelista escocés entre el salario material y el "salario de la vida". Es este último el que implica la entrega vital al ejercicio de la escritura y la dedicación absoluta a su dominio, como forma de existencia plena y aureolada por el brillo de la aventura y la propensión al conocimiento

${ }^{10}$ El marco argumental de las Cartas de Cadalso, dice Sánchez Blanco, “[...] las sacaría de los límites estrictos del ensayo. Pero, como no hay prácticamente más interacción entre los corresponsales que la mera comunicación de sus pensamientos, no encajan tampoco en los géneros novelístico o dramático" (32).

11 "Most of the faults in the poems I have been reading can be explained, I think, by the fact that they have been exposed to the fierce light of publicity while they were still too young to stand the strain. It has shrivelled them into a skeleton austerity, both emotional and verbal, which should not be characteristic of youth. The poet writes very well; he writes for the eye of a severe and intelligent public; but how much better he would have written if for ten years he had written for no eye but his own!” (Woolf 191).

Revista Iberoamericana, Vol. LXXVIII, Núm. 240, Julio-Septiembre 2012, 585-604
ISSN 0034-9631 (Impreso) 
puro y libre de la realidad y de uno mismo. El goce, la delectación y la "sensación de poder" pautan la vida del artista donde "ningún momento debe transcurrir sin deleite" (Stevenson, "Carta” 14). ${ }^{12}$ En esta misma clave de "consejo" desde la experiencia del maestro al iniciado, resulta evidente el cotejo con la primera de las cartas incluidas por Mario Vargas Llosa en su colección “al joven novelista”, donde presenta el artificio y estampa las primeras indicaciones a su innominado lector y receptor acerca de la dimensión pública que adquiere el escritor en vida.

El elogio de la vocación entronca con los planteamientos de Stevenson, pues se plantea al margen de toda asociación romántica, entendida por el peruano como “mitología vanidosa, teñida de religiosidad y soberbia” (Vargas Llosa, Cartas 1294), pero también dista de las orientaciones marcadas por el "voluntarismo de los existencialistas franceses” (1295), que evalúa Vargas Llosa como un rasgo propio de su juventud, matizado en la edad adulta. Este primer planteamiento de la "vocación” convoca ya el tono de "ensayo" propio del libro, ya que se perfila de modo libre y original como la innata predisposición del sujeto o proclividad para fantasear a la que se sumaría la “elección” posterior, donde sí emerge el elemento añadido del "voluntarismo” al que el peruano nunca renunció de modo drástico. La vocación, a su vez, tendría su origen en la rebeldía o “cuestionamiento esencial de la realidad” (1296), que trabaría el artista mediante el ejercicio de su postulación de una nueva dimensión, aquella donde asoma el edificio creado por esa "verdad de las mentiras" que perpetra el deicida escondido en todo fabulador auténtico. Como vemos, ya desde la primera carta se acomete la discriminación del ámbito teórico de la novela, merced a este entramado ficcional del autor novel, donde el cuestionamiento de la "vocación” no sólo compete a la educación profesional y también sentimental del iniciado sino, de modo evidente y explícito, al discernimiento de una poética de la ficción que, al hilo de las cartas, va articulándose: "La ficción es una mentira que encubre una profunda verdad; ella es la vida que no fue, la que los hombres y mujeres de una época dada quisieron tener y no tuvieron y por eso debieron inventarla" (1297), arguye en su exposición epistolar su redactor, tras su comentario sobre la vocación del joven novelista. El poder de ese "destino", evidentemente, no es inocuo, y por ello el joven escritor ha de estar alerto al modo en que encamina su vocación, evitando desviarse en el camino que podría enmascarar la esencia y naturaleza propias de toda inclinación al desenvolvimiento de una vida de artista. Es evidente, por tanto, el parangón con la “carta” también fictiva de Robert

12 "This is the practical side of art: its inexpugnable fortress for the true practitioner. The direct returns the wages of the trade are small, but the indirect-the wages of the life-are incalculably great. No other business offers a man his daily bread upon such joyful terms. The soldier and the explorer have moments of a worthier excitement, but they are purchased by cruel hardships and periods or tedium that beggar language. In the life of the artist there need be no hour without its pleasure” (Stevenson, "Letter” 184-85).

\footnotetext{
Revista Iberoamericana, Vol. LXXVIII, Núm. 240, Julio-Septiembre 2012, 585-604 ISSN 0034-9631 (Impreso) IISN 2154-4794 (Electrónico)
} 
Louis Stevenson, si bien no debemos olvidar las diferencias cualitativas que exhiben sus respectivas poéticas de la creación. Donde el escocés incide en las trampas posibles del éxito o la reputación, vira el peruano en la defensa de la vocación como "cruzada" vital que relativiza cualquier otro interés vital, convirtiendo la escritura en una "[...] dedicación exclusiva y excluyente, una prioridad a la que nada puede anteponerse, una servidumbre libremente elegida que hace de sus víctimas (de sus dichosas víctimas) unos esclavos" (Vargas Llosa, Cartas 1299). ${ }^{13}$

En total, doce son las cartas que integran el volumen, de las cuales la última funge como recapitulación, posdata y despedida al "joven novelista”, y la primera, como presentación de las coordenadas en que irá desarrollándose la supuesta comunicación epistolar. "Supuesta" en el sentido de que nos hallamos realmente ante una falsa correspondencia, ya que las cartas emitidas por el autor de las mismas (que desde el comienzo, como ya sabemos, hemos identificado con el autor histórico del volumen) no tienen respuesta "visible" en el conjunto de la obra, habiendo de presuponerse su contenido en virtud de los temas capitales que las cartas explícitas plasman. Así pues, la primera introduce esa "trama marco" en el territorio de la ficción, construyendo la personalidad fantasmal del joven escritor que reclama la atención del veterano para que su magisterio se transmita. La "respuesta" del consagrado contiene resonancias claramente autobiográficas que trazan vínculos y líneas de fuga con obras como El pez en el agua y pautan los compases argumentativos de las cartas, donde se dibuja el perfil del autor que se ve reflejado en el "otro”, espejo de sí mismo en la distancia del tiempo, activando de ese modo el resorte de su confesión autobiográfico-literaria:

Su carta me ha emocionado, porque, a través de ella, me he visto yo mismo a mis catorce o quince años, en la grisácea Lima de la dictadura del general Odría, exaltado con la ilusión de llegar a ser algún día un escritor, y deprimido por no saber qué pasos dar, por dónde comenzar a cristalizar en obras esa vocación que sentía como un mandato perentorio [...] (El pez en el agua 101) ${ }^{14}$

${ }_{13}$ Por su parte, insiste Stevenson en la vertiente moral de esta vocación a una vida de poeta, revelando los avatares externos como acechanzas de la fama o su reverso, el fracaso, en una llamada al estoicismo y la indiferencia frente a los factores externos a la propia práctica creativa: “And now you may perhaps ask me, if the debutant artist is to have no thought of money, and if (as is implied) he is to expect no honours from the State, he may not at least look forward to the delights of popularity? [...] A man may have done well for years, and then he may fail; he will hear of his failure. Or he may have done well for years, and still do well, but the critics may have tired of praising him, or there may have sprung up some new idol of the instant, some "dust a little gilt", to whom they now prefer to offer sacrifice. Here is the obverse and the reverse of that empty and ugly thing called popularity. Will any man suppose it worth the gaining?" (Stevenson, "Letter" 191-92).

14 Véase: "En los años que viví con mi padre, hasta que entré al Leoncio Prado, en 1950, se desvaneció la inocencia, la visión candorosa del mundo que mi madre, mis abuelos y mis tíos me habían inculcado. En esos tres años descubrí la crueldad, el miedo, el rencor, dimensión tortuosa y violenta que está siempre, a

\footnotetext{
Sinf Revista Iberoamericana, Vol. LXXVIII, Núm. 240, Julio-Septiembre 2012, 585-604 ISSN 0034-9631 (Impreso) ISSN 2154-4794 (Electrónico)
} 
Esta necesidad de "poner en entredicho" la realidad, de la que habla la Carta I, cabría ser enmarcada con diversos fragmentos de la autobiografía El pez en el agua, y su cotejo corroboraría la tesis de que sin el acicate de la denegación del mundo real no surgiría el estímulo de la reedificación del mundo imaginario que sostiene la arquitectura teórica del mundo literario de Mario Vargas Llosa. Así pues, el título de esta primera carta, la "Parábola de la solitaria", ${ }^{15}$ remite a esa instancia previa de un mundo que no satisface y del que partiría la voluntad por construir uno nuevo, en cuyo proceso el arquitecto ha de consagrar toda su energía y "sacrificar” su tiempo vital, entregándole cuerpo y alma a la "solitaria” que roe internamente su energía, y que no es otra que su necesidad imperiosa de materializar su vocación en obra escrita. En la base de esta interpretación sobre el fenómeno de la creación hallaríamos una teoría implícita de la literatura como la que implementa Jorge Luis Borges en diversas páginas de sus cuentos y poemas. Sin ir más lejos, su estremecedor poema "Ni siquiera soy polvo" imagina el momento de concepción de la figura de Don Quijote de la Mancha como el resultado de una denegación de la realidad existencial que le tocó “vivir” a su alter ego, Alonso Quijano $^{16}$ (e implícitamente, la que determinó la biografía de Miguel de Cervantes, como también cabe colegir de otro texto borgesiano como la "Parábola de Cervantes y de Quijote”, de El hacedor ${ }^{17}$ ). La metáfora de la solitaria es planteada en esta primera epístola como epítome de naturaleza biológica donde se combinan los componentes físico y espiritual de la ontología humana, implicando un proceso interno que devora el alimento en beneficio de su propio crecimiento: una larva, un parásito, un vampiro es la vocación literaria, confiesa Vargas Llosa en su primera carta al “joven novelista”,

veces más y a veces menos, contrapesando el lado generoso y bienhechor de todo destino humano. Y es probable que sin el desprecio de mi progenitor por la literatura, nunca hubiera perseverado yo de manera tan obstinada en lo que era entonces un juego, una vocación. Si en esos años no hubiera sufrido tanto a su lado, y no hubiera sentido que aquello era lo que más podía decepcionarlo, probablemente no sería ahora un escritor" (Vargas Llosa, Pez 101). Es interesante cotejar los fragmentos, y comprobar cómo esta confesión de las “memorias” confirma el "consejo” que el autor presta al “joven novelista” acerca del componente de rebeldía que hay implícito en la vocación de escritor.

15 El hecho de que las doce cartas vengan precedidas de títulos confirma la dimensión ficcional de la trama en que el ensayo se inserta, puesto que se trata de un procedimiento de clara raigambre novelística. Las “cartas reales” no suelen llevar títulos, sino meros encabezamientos, y las de Vargas Llosa no ahorran ninguno de los dos paratextos.

16 "No quiero ser quien soy. La avara suerte/ me ha deparado el siglo diecisiete,/ el polvo y la rutina de Castilla,/ las cosas repetidas, la mañana/ que, prometiendo el hoy, no da la víspera,/ la plática del cura y el barbero,/ la soledad que va dejando el tiempo/ y una vaga sobrina analfabeta” (Borges, Obra poética 533-34).

17 "Harto de su tierra de España, un viejo soldado del rey buscó solaz en las vastas geografías de Ariosto, en aquel valle de la luna donde está el tiempo que malgastan los sueños y el ídolo de oro de Mahoma que robó Montalbán. En mansa burla de sí mismo, ideó un hombre crédulo que, perturbado por la lectura de maravillas, dio en buscar proezas y encantamientos en lugares prosaicos que se llamaban El Toboso y Montiel...” (El hacedor 38).

\footnotetext{
Revista Iberoamericana, Vol. LXXVIII, Núm. 240, Julio-Septiembre 2012, 585-604 ISSN 0034-9631 (Impreso) ISSN 2154-4794 (Electrónico)
} 
significando con ello algo muy similar a lo que ya glosó en su ensayo sobre la "orgía perpetua" de Flaubert: "escribir es una manera de vivir". ${ }^{18}$

Este artificio metafórico es empleado también en la segunda epístola, "El catoblepas”. Evoca uno de los más enigmáticos "seres imaginarios” del catálogo elaborado por Jorge Luis Borges, adaptando la esencia del fantástico animal a su poética de la narración. ${ }^{19}$ Referida ya su naturaleza fantasmagórica y destructiva por autores como Plinio, el Viejo, o el propio Gustave Flaubert (en La tentación de San Antonio), articula el peruano la metáfora del novelista que se alimenta de sí mismo, tomando la materia fictiva que alienta en su interior y "escarbando en su propia existencia en pos de asideros para inventar historias” (Cartas 1303). La ideación del símbolo fantástico parte de un supuesto interés del "joven novelista" por un asunto capital del proceso creativo sobre el que interroga al escritor maduro, cifrado en el lugar donde se originan "las historias que cuentan las novelas”. La sabia respuesta ilustra su comentario con una alusión a Marcel Proust, emblema del "verdadero escritor catoblepas", "hurgando como un prolijo arqueólogo en todos los recovecos de su memoria", imagen cristalina y perfecta de un autor que "transformó los episodios bastante convencionales de su existencia en un esplendoroso tapiz” (1304).

Se trata, en suma, de una vindicación de la "vida vicaria” que acrisola el novelista a partir de la reconstrucción de sus experiencias personales, fenómeno que le permite a Vargas Llosa interpelar al neófito en un sentido que traspasa las fronteras del acto de escritura para instalarse en una categoría de orden ético. El escritor de novelas debe ser osado y tenaz; debe asimismo contar con una actitud de valentía y coraje a la hora de acometer su creación, puesto que la mayoría de los entes imaginarios que poblarán su universo emanarán de su interior, y habrán de manifestarse en muchas ocasiones tras una larga lucha y agonía para vivificar el territorio de la imaginación en concreción verbal. Los “fantasmas” o “demonios” de que habla en esta epístola Vargas Llosa remitirán, así pues, a las criaturas fictivas referidas por autores como Fiodor Dostoievski -o su gran vindicador en la literatura argentina, Ernesto Sábato-en la dimensión de los "fantasmas" que asaltan al escritor en su universo personal y que, a modo de "personajes en busca

${ }^{18}$ Citaba el autor estas palabras de Flaubert: "Un libro ha sido siempre para mí una manera especial de vivir, un medio de introducirme en un determinado medio”, de la cuales extraía Vargas Llosa los principios reguladores de su propia poética narrativa: "De las ruinas y disolución de la realidad real surgirá entonces algo muy distinto, una respuesta y no una copia: la realidad ficticia” (La orgía 85 y 91).

19 "Plinio (viii, 32) cuenta que en los confines de Etiopía, no lejos de las fuentes del Nilo, habita el Catoblepas. "Fiera de tamaño mediano y de andar perezoso. La cabeza es notablemente pesada y al animal le da mucho trabajo llevarla; siempre se inclina hacia la tierra. Si no fuera por esta circunstancia, el Catoblepas acabaría con el género humano, porque todo hombre que le ve los ojos, cae muerto". Catoblepas, en griego, quiere decir "que mira hacia abajo". Cuvier ha sugerido que el gnu (contaminado por el basilisco y por las gorgonas) inspiró a los antiguos el Catoblepas...” (Borges, Libro 55).

\footnotetext{
Revista Iberoamericana, Vol. LXXVIII, Núm. 240, Julio-Septiembre 2012, 585-604 ISSN 0034-9631 (Impreso) IISN 2154-4794 (Electrónico)
} 
de autor”, serán concebidos con esfuerzo y denuedo por ese “catoblepas” que es el novelista. ${ }^{20}$ De sus fijaciones y obsesiones surgirá ese paisaje con figuras que es la novela, imagen contumaz y derivada de su territorio espiritual e intelectivo, que construye su creador auto-devorándose. Nuevamente asomaría Jorge Luis Borges, en la constelación de referencias capitales, con el trasunto argumental de "Las ruinas circulares", relato en que precisamente se simboliza la creación literaria como acto fantástico de concebir vida en un ser forjado físicamente como la emanación carnal, pero simultáneamente inmaterial, de su hacedor.

Asimismo sobresale en esta segunda carta la reflexión que realiza el novelista maduro en torno a los dones que facultan al escritor para la realización veraz de sus escritos de ficción. Alude Vargas Llosa a la "autenticidad” y la "necesidad" como atributos imprescindibles para la consecución de una obra de arte. Aconseja, por tanto, escribir sobre temas que hayan brotado y discurrido en su interior a lo largo del tiempo y que merezcan aflorar y trasformarse en "mentira verdadera”, rehuyendo en consecuencia y parejamente "aquellos que no nacen íntimamente de su propia experiencia y llegan a su conciencia con carácter de necesidad” (Cartas 1307). Refrenda de este modo la advertencia que otro escritor consagrado, el poeta Rainer Maria Rilke, dictaminó al aprendiz Franz Xaver Kappus en las famosas Briefe an einer jungen Dichter [Cartas a un joven poeta], escritas y enviadas realmente a su destinatario entre 1903 y 1906. Interesa plantear la analogía entre ambos títulos, pero también subrayar la separación que media al relacionar a Rilke con Vargas Llosa, referida sobre todo al hecho de que las epístolas del escritor checo fueron testimonio histórico de un interés real que surgió en el poeta en ciernes hacia la figura del admirado maestro, ${ }^{21}$ y funciona como soporte fabulístico para dar cauce a un ensayo sobre la esencia de la novela. El tono y el espíritu de iniciación a la vida de artista que propone Vargas Llosa halla, no obstante su inspiración en el documento epistolar de Rilke, al que rinde homenaje con su obra. Prueba de ello son

${ }^{20}$ El motivo de los “demonios” particulares de todo escritor ya fue objeto de polémica cuando el peruano publicó su ensayo sobre García Márquez y la “suplantación de la divinidad” que operaba en el seno de todo novelista. La controversia entre Vargas Llosa y Ángel Rama fue reproducida por José Miguel Oviedo en su monográfico Mario Vargas Llosa. La invención de una realidad: “¿Qué es lo que objeta Rama en la teoría demoníaca de Vargas Llosa? La condena fundamentalmente por romántica, idealista, irracional, y por sacralizar la función del escritor, quien sería, otra vez, una especie de privilegiado semidiós tocado por lo demonios [...]. Las objeciones de Rama provienen del lado de la crítica sociológica de la literatura.” (319).

${ }^{21}$ En el prólogo a la edición de las Cartas que editó Kappus en 1929, tras la muerte de Rilke, el mismo Kappus narró el proceso de gestación de la relación epistolar: "Decidí enviar a Rainer Maria Rilke mis intentos poéticos, pidiéndole que los juzgara. Teniendo apenas veinte años, en el umbral de una carrera que sentía muy contraria a mis gustos, pensé que si alguien me debía comprender era el poeta de Mir zur Feier. Casi sin darme cuenta, nació una carta que acompañó a mis poesías: en ella me franqueaba más enteramente de lo que nunca había hecho y, por lo demás, de lo que nunca haría” (Rilke 18).

Revista Iberoamericana, Vol. LXXVIII, Núm. 240, Julio-Septiembre 2012, 585-604
ISSN 0034-9631 (Impreso) 
estos comentarios de índole espiritual que arropan los argumentos teóricos con materia poética, y donde hallamos la impronta del escritor checo en el temple pedagógico que se insinúa como más deseable para la formación del artista adolescente. Estas palabras de Rilke dejan claro eco en el tono y el contexto de la segunda carta sobre el "catoblepas”:

Nadie puede aconsejarle ni ayudarle, nadie. Hay sólo un único medio. Entre en usted. Examine ese fundamento que usted llama escribir; ponga a prueba si extiende sus raíces hasta el lugar más profundo de su corazón; reconozca que se moriría usted si se le privara de escribir. Esto, sobre todo: pregúntese en la hora más silenciosa de su noche: ¿debo escribir? Excave en sí mismo, en busca de una respuesta profunda. Y si ésta hubiera de ser de asentimiento, si hubiera usted de enfrentarse a esta grave pregunta [...], entonces construya su vida según esa necesidad: su vida, entrando hasta su hora más indiferente y pequeña, debe ser un signo y un testimonio de ese impulso. (Rilke 25)

Esta primera carta de Rilke a Kappus insiste, como vemos, en la “necesidad” a la que también Vargas Llosa apela en su segunda epístola. Las dos primeras de la colección “al joven novelista”, por lo tanto, recaban información en aspectos concernientes a la vida del autor, tanto en su vertiente biográfica cuanto en lo referido a la maduración moral de su personalidad. A partir de la tercera se centrará por el contrario su redactor en otra categoría, la de los procedimientos técnicos y las herramientas constructivas que han de ser manejadas de manera fehaciente y adecuada por un buen novelista. Así acontece en la titulada “El poder de la persuasión”, donde -en respuesta a las alusiones del joven corresponsal- arguye Vargas Llosa que sus anteriores cartas pecaban de abstractas, adquiriendo la “incómoda característica de ser inverificables” (Cartas 1309). Esta declaración marca la pauta de esa transición concernida al despliegue de otro tipo de contenidos en cuanto al orden prescrito para la presentación de la compilación epistolar. Desde un punto de vista crítico sobre el texto completo cabe expresar, no obstante, cierto reparo ante la declaración de intenciones que explicita el autor en el arranque de su tercera carta. Cabría incluso sospechar que, a despecho del auto-juicio que el escritor introduce en el seno de su obra, lo más valioso de la misma vendría a corresponder con las dos primera cartas, puesto que serían aquéllas donde más información en la línea de un ensayo hallaríamos, así como más agudas meditaciones sobre el mester de novelista, tendiendo las diez restantes -exceptuando la última que funge como cierre y despedida- a un acercamiento personal de un literato a la ciencia literaria, o a la teoría de la novela -en el seno de la "narratología”-, lo cual no desmerece la condición de explorador de la esencia del género, pero sí limita la cualidad más netamente ensayística que al comienzo encarece su originalidad y frescura. ${ }^{22}$

${ }^{22}$ En este sentido, las dos primeras cartas de Vargas Llosa estarían más en la línea de textos contemporáneos en el ensayismo hispanoamericano, como En esto creo (2002) de Carlos Fuentes, especie de diccionario

\footnotetext{
Revista Iberoamericana, Vol. LXXVIII, Núm. 240, Julio-Septiembre 2012, 585-604 ISSN 0034-9631 (Impreso) ISSN 2154-4794 (Electrónico)
} 
Cabría, pues, plantear el “corpus” comprendido entre la tercera y la decimoprimera -penúltima-carta como la poética narrativa del autor, instancia que puede interesarnos menos en lo tocante a la intención de "ensayo fictivo" que la colección adopta, pero que sin duda informa de modo sintético y funcional sobre las ideas axiales del novelista sobre materia narrativa. ${ }^{23}$ De este modo cabe entender la definición de la obra como "tratado", postulada por Joaquín Marco, quien no duda en tachar de "débil recurso epistolar" el establecimiento del marco ficcional que, sin embargo -y tal como ya hemos comentado en este trabajo- legitima a Mario Vargas Llosa como un ensayista nato y perspicaz, alguien capaz de referirse a una materia propia de la preceptiva o poética de un modo ocurrente y ameno, admitiendo en su discurso digresiones acerca de la naturaleza original del novelista, más allá de la necesaria ordenación temática y doctrinal de sus opiniones. Es cierto que "la fórmula epistolar le permite escasas expansiones autobiográficas", pero no porque dicha fórmula peque de estrechez per se, sino precisamente porque su autor deriva muy pronto hacia intereses más estrictos como teorizador sobre la novela: de ahí la "sistematización" de ideas aludida por Joaquín Marco. ${ }^{24}$

Esta tentativa de hallar un sistema, propia del "tratado" contenido en las "cartas", tendría, no obstante, su valor como recorrido panorámico que combina dos facetas de indudable interés: el muestrario de las ideas básicas del creador en el terreno de la ficción, por un lado, y la constatación del "canon” particular que su comentario arroja, de modo complementario. El primer ítem es, en realidad, el hilo conductor del ámbito más explícito del texto. Combina Vargas Llosa un repertorio de ideas que hallan en su conjunto formulación definitiva. La tesis sobre la "autosuficiencia" novelesca parte del "poder de persuasión" ínsito en la capacidad demiúrgica o deicida del fabulador. Ese "apetito deicida" -al que ya se refirió larga y abundantemente el peruano como exégeta de Gabriel García Márquez- sólo podrá ser aplicado una vez que el narrador

temático de raigambre personal que sirve como pretexto para el desarrollo de micro-ensayos sobre múltiples aspectos heterogéneos. Sin embargo, el carácter de iniciación y de ensayo, apto para la formación del "artista adolescente”, entroncaría la obra no tanto con la dimensión contemporánea del ensayo, sino con funciones clásicas, más propias de su cultivo durante el siglo xix o las primeras décadas del xx. No olvidemos que un ensayo emblemático como Ariel de José Enrique Rodó, publicado en 1900, se dirige a la "juventud de América" como receptor ideal, y adopta asimismo el esquema imaginario de una clase donde el maestro Próspero se despide de sus estudiantes.

23 Así lo concibe la crítica, al señalar que en sus “Cartas” el autor "resume con sencillez su pensamiento ya conocido sobre técnicas y propósitos narrativos, incorporando comentarios sobre sus novelas favoritas" (Skirius 641).

${ }^{24}$ Es cierto que "las Cartas pueden entenderse como un rico estudio sobre la novela y los métodos para profundizar en su lectura, siguiendo, incluso, fórmulas críticas más tradicionales” (Marco 25-26), pero entiendo que no es ésta la mayor hazaña de la obra, que a mi juicio residiría más bien en los pasajes donde los comentarios personales marcan el camino para que el "joven novelista” anónimo e impersonal emprenda su itinerario, como ya hemos visto reflejado en la exégesis de las dos primeras epístolas.

Revista Iberoamericana, Vol. LXXVIII, Núm. 240, Julio-Septiembre 2012, 585-604 ISSN 0034-9631 (Impreso) ISSN 2154-4794 (Electrónico) 
rehaga un mundo deshecho por su connatural rebeldía (Carta III). La persuasión, a su vez, será identificada por Varga Llosa con el concepto clásico de "verosimilitud” en la Carta IV, donde discurre sobre la eficacia de la invención en relación directamente proporcional a la capacidad de "fingimiento" que posee el hacedor-deicida. ${ }^{25}$ Aboga por la "invisibilidad del narrador” en su capítulo dedicado a dicho "personaje” en la Carta V, siguiendo de nuevo la poética de Gustave Flaubert, ${ }^{26}$ ilustrando como contrapuesto paradigma (narrador visible, pero poderoso y necesario) al que forjó Victor Hugo en Los miserables. ${ }^{27}$ La consistencia del autor frente al narrador como poseedor de una “vida más rica y diversa” resulta de una evidencia peligrosa. No tendríamos más que comparar su planteo con las propuestas idealistas de un Macedonio Fernández, que fabuló páginas y más páginas de su Museo de la novela de la eterna para mantener con “vida” al narrador y a los personajes para que disfrutaran así de una existencia menos perecedera de la que el “autor” histórico alcanzaría como criatura mortal.

Originales son los planteamientos que realiza Vargas Llosa a partir de las coordenadas espacio-temporales y de los niveles de realidad implícitos, imprescindibles para producir ese efecto de verdad que las mentiras del novelista encumbran a la categoría de creación verosímil soportada por su “poder de persuasión”, aspectos que cubrirán lo más granado de las Cartas VI y VII. Como ya hiciera en ensayos anteriores (Historia de un deicidio, La orgía perpetua, La verdad de las mentiras) acierta el peruano al concretar una terminología personal para referirse a los "tiempos vivos" existentes en las novelas como "cráteres", que serían los episodios narrativos de máxima concentración de las vivencias o aquellos donde el tiempo parece condensarse y manifestarse al lector de una manera tremendamente vívida, acaparando por completo su atención. Por su parte, los “tiempos muertos o transitivos" reciben este nombre por referirse a los "periodos

25 Ilustra el argumento con el tan citado monólogo de Molly Bloom, del Ulysses de James Joyce, cuya eficacia radica en que "es una invención literaria tan poderosamente convincente que nos parece reproducir el deambular de la conciencia de Molly cuando, en verdad, lo está inventando” (Cartas 1315).

${ }^{26}$ No azarosamente será la alusión a la novela predilecta de Flaubert uno de los momentos de mayor cercanía entre el autor y su personaje (el "joven novelista"), a quien interroga confidencialmente sobre el comienzo de Madame Bovary, y al que también cuestiona al final de esta Carta IV sobre la posible valoración que un aprendiz de escritor puede realizar acerca de las técnicas novelescas.

${ }^{27}$ Este comentario permite una sutil incursión en esta excepcional novela francesa a la que, como ya vimos, dedicará un volumen independiente años más tarde. En las “Cartas” señala la bifurcación en cuanto al uso de la voz narrativa de Los Miserables en la combinación de dos historias paralelas: la de los personajes con todas sus anécdotas narrativas y la segunda, propia del narrador mismo, cuyas inserciones componen "el contexto intelectual, un telón de fondo ideológico-filosófico-moral de lo narrado.” (Vargas Llosa, Cartas 1331) En efecto, en La tentación de lo imposible insiste Vargas Llosa en estos términos: “El personaje principal de Los Miserables no es monseñor Bienvenu, ni Jean Valjean, ni Fantine, ni Gavroche, ni Marius, ni Cosette, sino quien los cuenta y los inventa, ese narrador lenguaraz que está continuamente asomando entre sus criaturas y el lector”: el “divino estenógrafo”” (Vargas Llosa, Tentación 28).

Revista Iberoamericana, Vol. LXXVIII, Núm. 240, Julio-Septiembre 2012, 585-604
ISSN 0034-9631 (Impreso) 
en que, por el contrario, la intensidad decae y amengua la vitalidad de los episodios” (1344-45). Importantes teóricos de la novela como E. M. Forster, Mijail Bajtin, Milan Kundera, Roland Bourneuf, Ricardo Gullón, Mariano Baquero Goyanes, Carmen Boves Naves o Manuel García Viñó establecerían aquí sus propias pautas hermenéuticas, pero sin duda coincidirán en la comprensión del fenómeno de la intensidad de los “cráteres” como una de las máximas aspiraciones de todo novelista. ${ }^{28}$ Tampoco sería fácil refutar la idea, derivada de su reflexión teórica, sobre ese "gran triunfo de la técnica novelesca” que, para Vargas Llosa, consiste en “alcanzar la invisibilidad” en el desarrollo expositivo de una trama ficcional, de tal modo que la creación se convierta en un modo efectivo de “suplantar la vida” (Vargas Llosa, Cartas 1356), trascendiéndola. Así entroncaría el peruano en su voluntad y deseo de obtener esa sensación de vida en la fabulación novelística con una de las máximas que estampó hacia 1921 Horacio Quiroga en su Decálogo del perfecto cuentista, donde también aventuró esa función palingenésica del arte como decreto para que el "futuro cuentista" aprovechara su larga experiencia en el manejo del relato: "Cuenta como si el relato no tuviera interés más que para el pequeño ambiente de personajes, de los que pudiste haber sido uno. No de otra forma se obtiene la vida en el cuento" (xxiv). ${ }^{29}$

Otras cuestiones también de relieve para todo artífice de novelas son referidas en las últimas cartas de la compilación. Merece destacarse el buen uso del término "muda” ya frecuentado en obras previas por el autor para una amplia aplicación que abarca las categorías espaciales, temporales y los niveles de realidad. Como “cataclismo ontológico” define el "salto cualitativo" que supone la mudanza de sexo en el personaje protagonista de Orlando, de Virginia Woolf (1359), y como "muda macabra” se refiere a la que los lectores operan en el juego de planos ontológicos ofrecido por Juan Rulfo en Pedro Páramo (1362). La incursión en el género fantástico le permite remitirse a los conceptos de Roger Caillois y Julio Cortázar para estimular el conocimiento del género en el "joven novelista”, y a Juan Carlos Onetti habrá de convocar como ejemplo excelso del uso de la "caja china” con reminiscencias metafísicas en la literatura contemporánea. El arte de la omisión, a su vez, será ilustrado con textos de Ernest Hemingway y Edgard Allan Poe en la Carta X, y el recurso estructural de los “vasos comunicantes” le permitirá

${ }^{28}$ Menos acertada, a mi juicio, resulta la identificación entre el punto de vista con la voz narrativa que hallamos en la Carta V, que adolece de confusión y endeble deslinde, aunque resulta coherente con la exposición teórico-ensayística que realiza Vargas Llosa. Esta ecuación le conduce a interpretar como "muda espacial” un cambio de voz narrativa, empleando así una terminología que pudiera resultar algo confusa.

29 Se trata del último de los mandamientos que estableció el escritor uruguayo y, sin duda, el que más conviene en su correlato con la función didáctica de las Cartas a un joven novelista, coincidiendo en su voluntad de construcción de ese universo autónomo con vida propia que es la novela (o el cuento para Quiroga).

\footnotetext{
Revista Iberoamericana, Vol. LXXVIII, Núm. 240, Julio-Septiembre 2012, 585-604 ISSN 0034-9631 (Impreso) ISSN 2154-4794 (Electrónico)
} 
bascular en la alusión a un autor tan caro a su sensibilidad y formación como William Faulkner. En todo caso, los comentarios teóricos derivan siempre de la categoría de "tratado" (más o menos narratológico) hacia una mayor flexibilidad ensayística que resulta del manejo de la trama ficcional. La simulación le permite apartarse siempre del rigor y proponer nociones de carácter genérico y personal que serían vedadas a un teórico de la novela, como cabe deducir del final de la Carta X. Señala Vargas Llosa en ese punto: "Quizás valdría la pena, antes de terminar esta carta, hacer una reflexión general, válida para todas las novelas, respecto a una característica innata del género, de la cual se deriva el procedimiento de la caja china” (Cartas 1378), y con ello alude al motivo de esa historia, relato o fábula de carácter absoluto, que abarca un ingente e inabordable material narrativo resultante de una labor de arquitectura vasta y compleja donde se alberga esa simulación de mundo al que siempre propendió todo "joven" -o menos joven- novelista: ${ }^{30}$ la aspiración a la "novela total". ${ }^{31}$

En cuanto al canon personal de Vargas Llosa que se desprende de este epistolario apócrifo, conviene precisar que en este caso nos hallamos de nuevo ante una visión compendiadora de los grandes nombres que acrisolan la biblioteca personal del autor. El "panteón privado" del artista se plasma en las cartas a modo de reconocimiento plagado de fe hacia el "maestro", tal como dictaminó el ya citado Horacio Quiroga en el primer mandamiento de su Decálogo al "perfecto cuentista”. En este caso, los maestros más reconocidos apuntan al territorio del existencialismo francés (Jean Paul Sartre, Albert Camus, André Malraux) junto a la nómina de los autores de la generación de primera mitad de siglo xx norteamericana o "lost generation" (Ernest Hemingway, William Faulkner, John Dos Passos, Francis Scott Fitzgerald). A la hora de establecer dicotomías, es radical en su elección: entre Tolstoi y Dostoievski se decanta por el primero, como es lógico deducir atendiendo a los puntales temáticos de su producción narrativa. En la literatura iberoamericana destacan los nombres de João Guimarães Rosa, Alejo Carpentier, Juan

\footnotetext{
${ }^{30}$ Y que el propio Mario Vargas Llosa ejecutó en títulos como La guerra del fin del mundo (1981) o La fiesta del chivo (2000).

31 "Porque el anhelo de una novela total no es un expediente para justificar el empleo de técnicas muy complejas; es sólo el instrumento plural para hallar la verdad esencial de lo existente”, señala José Miguel Oviedo refiriéndose en concreto a la fascinación que la lectura del Tirant lo Blanc de Joanot Martorell produjo en el novelista peruano al poco tiempo de ingresar en la Universidad. A juicio de Vargas Llosa, Martorell sería el primero de la estirpe de suplantadores de Dios, en una línea donde hallaríamos a Fielding, Balzac, Dickens, Flaubert, Joyce o Faulkner, y que se caracteriza por la propensión a edificar una 'realidad total'” (Oviedo, Mario 68). Vargas Llosa desarrolla ampliamente esta cuestión en su Historia de un deicidio. Véase "El proceso de edificación de la realidad ficticia alcanza con Cien años de soledad su culminación: esta novela integra en una síntesis superior a las ficciones anteriores, construye un mundo de una riqueza extraordinaria, agota este mundo y se agota en él. Difícilmente podrá hacer una ficción posterior con Cien años de soledad lo que esta novela hace con los cuentos y novelas precedentes: reducirlos a la condición de anuncios, de partes de una totalidad” (533).
}

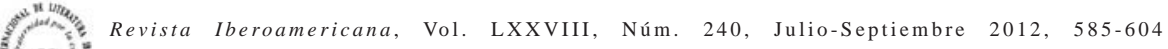
ISSN 0034-9631 (Impreso) $\quad$ ISSN 2154-4794 (Electrónico)
} 
Carlos Onetti, Juan Rulfo, Gabriel García Márquez, Julio Cortázar y, sobre todo, Jorge Luis Borges, de quien elogia en las cartas haber logrado un estilo "inconfundible, dotado de extraordinaria funcionalidad" que se humaniza "gracias a la sutil ironía, fresca brisa que aligera la complejidad de sus razonamientos” (Cartas 1318). Aúna en la categoría de maestros de la manipulación temporal a autores como Ambrose Bierce, Laurence Sterne, Günter Grass o H. G. Wells y, asimismo, encumbra como grandes creadores en el ámbito del ensayo a los "críticos como artistas" en la acepción que imprimió Oscar Wilde al término: Dámaso Alonso, Edmund Wilson, John Livingstone Lowes o el teórico del jansenismo decimonónico Charles Agustine Sainte-Beuve (1388). Como decretara tiempo atrás Alfonso Reyes en su “Aristarco o la anatomía de la crítica”, la función del teórico o ensayista surge como una segunda naturaleza del propio escritor, que indaga en los territorios donde quiso penetrar sin salvaguardia, y que con el paso del tiempo procedería a emanciparse progresivamente de ese cuerpo (el creador) del que emergió como su sombra (95). Probablemente la obra ensayística de Mario Vargas Llosa ilustre el inspirado aserto del maestro mexicano.

En "La búsqueda del punto cero" sostenía Maurice Blanchot, a partir de las premisas teóricas de Roland Barthes, que la experiencia literaria siempre lo es de manera "total"; contiene una pasión por sí misma que "fuerza a aquel que atrae a entrar por completo” en ella (246). Medio siglo más tarde, Mario Vargas Llosa refrenda la opinión del filósofo francés, y lo hace a modo de síntesis del pensamiento teórico y ensayístico que el propio novelista había producido. Lo construye a modo de epístolas apócrifas, donde la sabiduría de esa experiencia irrenunciable rezuma y se convierte en don, en ofrecimiento y tributo para el artista adolescente que "quiere abrazar la carrera de escritor”, como señalara con acierto Robert Louis Stevenson en la carta que sirvió de modelo formal a Vargas Llosa. Las Cartas a un joven novelista suponen un punto de inflexión en la trayectoria ensayística del autor, dado que ofrecen lo más granado y definitivo de su inquisición sobre la experiencia literaria. En el contexto del ensayo hispanoamericano recoge el legado de una función primordial en la historia del género, la pedagógica. El peruano acepta y releva la antorcha que encendiera José Enrique Rodó cuando comprendió que el marco ficcional más oportuno para la oportuna fertilización de sus ideas americanistas era el magisterio, por lo que los postulados de su obra se enmarcarían en el testimonio docente de un maestro de la juventud. Las palabras con que cierra Vargas Llosa su colección de cartas tributan veladamente un homenaje al gran forjador del ensayo hispanoamericano contemporáneo de raigambre formativoeducativa, con ese estímulo a la acción de quien ha sabido extraer de su experiencia estética lo sustantivo, pero no como objeto de imitación, sino como acicate para un nuevo impulso: "Querido amigo:" -concluye la carta final- "estoy tratando de decirle que se olvide de todo lo que ha leído en mis cartas sobre la forma novelesca y se ponga a escribir novelas de una vez" (Cartas 1389).

\footnotetext{
Revista Iberoamericana, Vol. LXXVIII, Núm. 240, Julio-Septiembre 2012, 585-604 ISSN 0034-9631 (Impreso)

ISSN 2154-4794 (Electrónico)
} 
Y en el contexto del ensayo hispanoamericano actual, las Cartas ofrecen un testimonio atípico, que lejos de buscar la originalidad epistemológica en el ámbito del género, se postulan como un ejercicio de sinceridad intelectual y de contundencia crítica. Se trata de un homenaje a la historia de la literatura, más allá de las premisas de la originalidad, como búsqueda y orgía perpetuas. Y así, las ideas con mayúsculas que vertebraron buena parte del Texto narrativo del siglo xx se recuperan como legado, como testimonio, como enseñanza, como homenaje y como alimento. Vargas Llosa vivifica el pensamiento constructor de los maestros y veteranos en el arte de novelar... pero también en el arte de "ensayar" y condensar el conocimiento acumulado y ofrecerlo como el mejor de los presentes a las generaciones que seguirán cultivando la "ciudad letrada" en el reino de este mundo:

Por eso, nadie puede enseñar a otro a crear; a lo más, a escribir y leer. El resto, se lo enseña uno a sí mismo tropezando, cayéndose y levantándose, sin cesar. (Cartas 1389)

BiBLIOGRAFÍA

Blanchot, Maurice. El libro por venir. 1959. Cristina de Peretti y Emilio Velasco, trads. Madrid: Trotta, 2005.

Borges, Jorge Luis. El hacedor. 1960. Buenos Aires: Emecé, 1967.

En colaboración con Margarita Guerrero. El libro de los seres imaginarios. Barcelona: Bruguera, 1983.

Obra poética. Buenos Aires: Emecé, 1989.

Caldaso, José. Cartas marruecas. Mairena del Aljarafe (Sevilla): Extramuros, 2007.

Cervera Salinas, Vicente. "Elogio de la experiencia literaria como orgía perpetua”.

Diálogo del conocimiento. Encuentros con Mario Vargas Llosa. Murcia: CajaMurcia-Novograf, 1994. 109-26.

Belén Hernández, María Dolores Adsuar, eds. El ensayo como género literario. Murcia: Servicio de Publicaciones de la Universidad, 2005.

Charles de Secondat Montesquieu, Baron de. Cartas Persas. Madrid: Cátedra, 1997. Letras Universales, 253.

Feijoo, Benito Jerónimo. Cartas eruditas curiosas. Madrid: Alianza, 1970. 225.

Fernández, Macedonio. Museo de la novela de la eterna. Caracas: Biblioteca Ayacucho, 1982.

Fuentes, Carlos. En esto creo. México: Seix Barral, 2002.

Joyce, James. Ulises. Barcelona: Tusquets, 2004.

Lukács, György. "Sobre la esencia y forma del ensayo”. El alma y las formas. 1911. Manuel Sacristán, trad. Barcelona: Grijalbo, 1975. 15-39.

Marco, Joaquín. Prólogo. Ensayos literarios I. Obras completas. Vol. VI. Barcelona: Galaxia Gutenberg-Círculo de Lectores, 2006. 9-29.

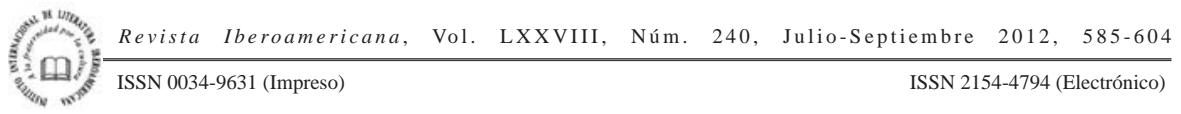


Oviedo, José Miguel. Breve historia del ensayo hispanoamericano. Madrid:Alianza, 1991. Mario Vargas Llosa. La invención de una realidad. Barcelona: Barral, 1977.

Quiroga, Horacio. "Decálogo del perfecto cuentista”. Cuentos. 1927. México: Porrúa, 1985.

Reyes, Alfonso. “Aristarco o anatomía de la crítica”. La experiencia literaria. 1942. México: Fondo de Cultura Económica, 2004. 92-104.

Rilke, Rainer Maria. Cartas a un joven poeta. 1929. José María Valverde, pról. y trad. Madrid: Alianza, 1993.

Rodó, José Enrique. Ariel; Motivos de Proteo. Ángel Rama, ed. Caracas: Biblioteca Ayacucho, 1976.

Sánchez Blanco, Francisco, ed. El ensayo español. Vol 2: El siglo XVIII. Barcelona: Crítica, 1998.

Skirius, John, comp. El ensayo hispanoamericano del siglo XX. 1981. México: Fondo de Cultura Económica, 2004.

Stevenson, Robert Louis. "Carta a un joven que se propone abrazar la carrera del arte". Ensayos literarios. Beatriz Canals y Juan Ignacio de Laiglesia, trads. Madrid: Hiperión, 1983. 11-19.

"Letter to a Young Gentleman Who Proposes to Embrace the Career of Art". Across the Plains: With Other Memories and Essays. 1888. Nueva York: Cosimo, 2005. 182-92.

Tejada Caller, Paloma. "El género epistolar: consideraciones sobre su utilidad en la enseñanza de una segunda lengua”. Estudios ingleses de la Universidad Complutense 1 (1993): 179-90.

Vargas Llosa, Mario. Cartas a un joven novelista. 1997. Ensayos literarios I. Obras Completas Vol. VI. Barcelona: Galaxia Gutenberg-Círculo de Lectores, 2006. 1291-1389.

La fiesta del chivo. Madrid: Alfaguara, 2000.

García Márquez: historia de un deicidio. 1971. Ensayos literarios I. Obras Completas Vol. VI. Barcelona: Galaxia Gutenberg-Círculo de Lectores, 2006. 109-708.

La guerra del fin del mundo. Barcelona: Seix Barral, 1981.

La orgía perpetua. 1975. Barcelona: Seix-Barral, 1989.

El pez en el agua. Barcelona: Seix-Barral, 1993.

La tentación de lo imposible. Victor Hugo y Los Miserables. Madrid: Alfaguara, 2004.

La utopía arcaica: José María Arguedas y las ficciones del indigenismo. México:

Fondo de Cultura Económica, 1996.

La verdad de las mentiras.1990. Madrid: Suma de letras, 2007.

El viaje a la ficción: el mundo de Juan Carlos Onetti. Lima: Alfaguara, 2008.

Revista Iberoamericana, Vol. LXXVIII, Núm. 240, Julio-Septiembre 2012, 585-604
ISSN 2154-4794 (Electrónico) 
Woolf, Virginia. “A Letter to a Young Poet”. The Death of the Moth and Other Essays. Collected Essays. 1932. Nueva York: Harcourt, Brace \& World, 1967. 182-95.

ISSN 0034-9631 (Impreso) 